\title{
ANALISIS HUBUNGAN KESEHATAN MENTAL TERHADAP HASIL BELAJAR ANAK 5-6 TAHUN
}

\author{
Nurhasanah \\ Fakultas Ilmu Perguruan dan Pendidikan, Universitas Muhammadiyah Sukabumi. \\ nurhasanahsantoso147@gmail.com \\ Nurhasanah. (2021). Analisis Hubungan Kesehatan Mental Terhadap Hasil Belajar Anak 5-6 Tahun Kabupaten \\ Sukabumi. Jurnal Pelita PAUD, 6(1), 74-80. \\ doi: https://doi.org/10.33222/pelitapaud.v6i1.1407
}

Diterima: 28-07-202

Disetujui: 05-08-2021

Dipublikasikan: 24-12-2021

\begin{abstract}
Abstrak: Kondisi kesehatan mental anak usia dini merupakan salah satu aspek perkembangan yang harus diperhatikan dan dikembangkan karena kesehatan mental anak akan sangat berpengaruh terhadap perkembangan yang ditunjukkan oleh anak salah satunya dalam hasil belajarnya. Maka dari itu, penelitian ini dilakukan untuk melakukan analisis pentingnya kesehatan mental anak sehingga dapat berpengaruh terhadap hasil belajar anak usia 5-6 tahun di Kecamatan Parungkuda, dengan 43 pendidik sebagai sampel penelitian. penelitian ini menggunakan metode survey dengan hasil yang menyatakan bahwa kesehatan mental memiliki hubungan yang kuat dan positif terhadap hasil belajar anak dengan nilai koefisien determinasi sebesar 44,22\%. Artinya, hasil belajar anak 44,22\% dipengaruhi oleh kesehatan mentalnya. Hal ini didukung oleh hasil nilai signifikansi hasil olah data lapangan yang menunjukkan bahwa kesehatan mental berpengaruh secara signifikan terhadap hasil belajar anak usia 56 tahun di Kabupaten Sukabumi.
\end{abstract}

Kata Kunci: kesehatan mental, hasil belajar, pendidikan anak usia dini

Abstract: The mental health condition of early childhood is one aspect of development that must be considered and developed because the mental health of children will greatly affect the development shown by children, one of which is in their learning outcomes. Therefore, this study was conducted to analyze the importance of children's mental health so that it can affect the learning outcomes of children aged 5-6 years in Parungkuda District, with 43 educators as research samples. This study uses a survey method with the results stating that mental health has a strong and positive relationship to children's learning outcomes with a coefficient of determination of $44.22 \%$. This means that $44.22 \%$ of children's learning outcomes are influenced by their mental health. This is supported by the results of the significance value of the results of field data processing which shows that mental health has a significant effect on the learning outcomes of children aged 5-6 years in Sukabumi Regency.

Keywords: mental health, learning outcomes, early childhood education 


\section{PENDAHULUAN}

Anak merupakan generasi penerus bangsa yang dalam proses perkembangannya lingkungan sekitar menjadi salah satu peentunya. Lingkungan tersebut ialah lingkungan keluarga, sekolah dan masyarakat. Dalam pendidikannya, pihak yang bersangkutan hars menciptakan lingkungan yang baik bagi perkembangan kesehatan fisik maupun mentalnya (Puspita, 2019). Pendidikan anak usia dini merupakan suatu pendidikan pondasi yang membantu anak untuk tumbuh dan berkembang secara optimal. Sesuai dengan tujuan Pendidikan Nasional dalam (Suwardi et al., 2016) yakni Pendidikan Nasional bertujuan mencerdaskan kehidupan bangsa dan mengembangkan manusia Indonesia seutuhnya, yaitu manusia yang beriman dan bertaqwa terhadap Tuhan Yang Maha Esa dan berbudi pekerti luhur, memiliki pengetahuan dan keterampilan, kesehatan jasmani dan rohani, kepribadian yang mantap dan mandiri serta rasa tanggungjawab kemasyarakatan dan kebangsaan. Perkembangan yang optimal ialah ketika anak memiliki perkembangan sesuai dengan tahapan usianya. Dalam pendidikan anak usia dini, perkembangan anak dapat dilihat dari berbagai macam aspek maupun kegiatan salah satunya ialah hasil belajar anak dari sebuah proses pembelajaran. Hasil belajar merupakan salah satu referensi penilaian pendidik terhadap perkembangan anak selain dari pada bagaimana proses dalam pembelajaran tersebut (Pane, 2017). Hasil belajar anak usia dini yaitu serangkaian aktivitas mengukur dan menilai pencapaian kemampuan anak usia dini pada aspek-aspek perkembangannya secara menyeluruh dalam proses pembelajaran (Safitri \& Miranda, 2009).

Hasil belajar anak usia dini dapat dipengaruhi oleh faktor internal dan eksternal. Faktor internal ialah semangat, motivasi diri dan juga kesehatan baik fisik maupun mental anak. Undang-Undang No 23 Tahun 1992 menyebutkan bahwa sehat adalah keadaan sejahtera dari badan (jasmani), jiwa (rohani) dan sosial yang memungkinkan setiap orang dapat hidup produktif secara sosial dan ekonomis (Fuadi Husin, 2014). Sedangkan menurut (Dewi, 2012) Sehat merupakan suatu kesejahteraan secara umum atau sempurna baik secara fisik, mental ataupun sosialdan tidah hanya terhindar dari kondisi lemah dan penyakit saja.

Mental emosional merupakan suatu upaya untuk menyesuaikan diri dengan lingkungan dan pengalaman-pengalamannya (Rizkiah et al., 2020). Kondisi mental atau kesehatan mental merupakan hal yang sangat penting seperti halnya kesehatan fisik pada umumnya. Masalah pada kesehatan mental emosional anak akan menurunkan produktivitas dan kualitas hidup anak serta menghambat perkembangannya. Kesehatan mental anak sangat erat kaitannya dengan kecerdasan emosional yang dimiliki anak. Menurut (Fitriyani, 2015) "Kecerdasan emosi merupakan kecerdasan yang memusatkan perhatian dalam mengenali, memahami, merasakan, mengelola, dan memotivasi baik diri sendiri maupun orang lain serta dapat mengaplikasikan kemampuan tersebut dalam kehidupan pribadi dan sosialnya". Maka perlu memberikan pendidikan kepada anak untuk memiliki kecerdasan emosional yang berguna untuk mengendalikan emosi dengan memotivasi diri dan bertahan dalam menghadapi situasi permasalahan, tidak melebihkan rasa senang, menghadapi frustasi, mengatur suasana hati dan terhindar dari stres, tetap meningkatkan kemampuan berpikir, berempati dan berdoa (Susilowati, 2018).

Kata mental sendiri berasal dari kata Yunani yang artinya psyche dalam bahasa latin berarti psikis, jiwa atau kejiwaaan. Kesehatan mental setiap individu berbeda-beda dan mengalami ritme dalam perkembangannya karena pada hakekatnya manusia dihadapkan pada kondisi dimana ia harus dapat menyelesaikan permasalahan dengan berbagai alternatif pemecahannya dan tidak sedikit orang pada waktu tertentu mengalami masalah-masalah kesehatan mental dalam hidupnya (Fakhriyani, 2019). Dengan sehatnya mental seseorang maka aspek kehidupan yang lain dalam dirinya akan 
bekerja secara lebih maksimal (K \& Dewi Aisyah, 2021).

Menurut Zakiyah Daradjat (dalam Ariadi, 2013), karakteristik mental yang sehat ialah, terhindar dari gangguan jiwa; penyesuaian diri (self adjustmenti); pemanfaatan potensi maksimal dan tercapainya kebahagiaan pribadi dan orang lain. Faktor-faktor yang dapat melindungi anak dari gangguan kesehatan mental diantaranya: kecerdasan emosi, dicintai dan merasa aman, tinggal dilingkungan rumah yang stabil, pekerjaan orang tua juga cukup mempengaruhi terhadap kesehatan mental, karena akan berdampak pada faktor ekonomi keluarga, orang tua yang baik dan kesehatan mental orang tua yang baik serta kegiatan rutinitas dan minat anak, hubungan yang positif dengan sesamanya, ketahanan emosional dan berfikir positif juga rasa humor (Suminar \& Hamidah, n.d.).

\section{METODE PENELITIAN}

Penelitian ini dilakukan di wilayah Kabupaten Sukabumi dengan sasaran penelitian ialah para pendidik PAUD,dimana mereka memiliki pern untuk mengamati dn menelaah kodisi keesehatan mental anak selama di sekolah. Peneliti melakukan studi pendahuluan serta meninjau kasus-kasus yang terjadi diKabupaten Sukabumi yang mengakibatkan kesehatan mental anak menjadi terganggu untuk selanjutnya dilakukan survey untuk mengetahui hubungan antara kesehtan mental terhadap hasil belajar anak usia 5-6 tahun di Kabupaten Sukabumi.

\section{Jenis Penelitian}

Penelitian ini menggunakan pendekatan kuantitatif dengan desain penelitian survey untuk mencari fakta dan fenomena sebab akibat di lapangan yang berkaitan dengan kesehatan mental dan hasil belajar anak. Dengan jenis penelitian ini, peneliti dapat membuat kesimpulan apakah kesehatan mental memiliki hubungan positif terhadap hasil belajar anak.

\section{Waktu dan Tempat Penelitian}

Penelitian dilakukan dalam kurun waktu 6 bulan diawali dengan permasalhan yang ditemukan pada saat studi pendahuluan dilakukan hingga pada akhir penulisan laporan. Tempat penelitian yaitu di Kabupaten Sukabumi.

\section{Subjek Penelitian}

Populasi dalam penelitian ini ialah seluruh pendidik lembaga PAUD di Kabupaten Sukabumi dengan sampel penelitian salah satu Kecamatan yang ada di Kabupaten Sukabumi yaitu Kecamatan Parungkuda, dengan jumlah responden sebanyak 43 pendidik PAUD yang berasal dari formal dan non formal.

\section{Prosedur Penelitian}

Penelitian ini diawali dengan mengamati permasalahan yang terjadi di lingkungan Kabupaten Sukabumi yang berkaitan dengan berlangsungnya Pendidikan Anak Usia Dini, lalu kemudian peneliti merancang proposal penelitian dan kemudian disetujui oleh dosen pembimbing dan pihak fakultas untuk selanjutnya melanjutkan penelitian di lembaga PAUD di Kabupaten Sukabumi.

\section{Teknik Pengumpulan Data}

Peneliti menggunakan angket/kuisioner sebagai alat pengumpulan data. Angket ini memiliki 17 poin pernyataan yang berkaitan dengan variabel $X$ yaitu kesehatan mental dan juga variabl $Y$ yaitu hasil belajar anak usia 5-6 tahun. instrumen penelitian berupa kuisioner ini telah melalui proses uji validitas yang dilakukan untuk mengetahui apakah kuisioner yang digunakan tersebut valid atau tidak, dan uji reliabilitas yang dilakukan untuk menguji keajegan atau konsistensi suatu instrumen jika digunakan beberapa kali (Yusup, 2018). Dan didapatkan hasil bahwa kuisioner yang digunakan valid dan juga reliabel. Pengisian angket dalam penelitian ini dilakukan oleh 43 orang pendidik PAUD kelompok usia 5- tahun atau kelompok B, untuk selanjutnya data yang di dapatkan akaan diolah untuk mendpatkan suatu kesimpulan dalam penelitian.

\section{Teknik Analisis Data}

Teknik analisis data dilkukan untuk menjawab hipotesis yang telah diajukan oleh peneliti. Namun sebelum melakukan uji hipotesis peneliti melakukan uji prasayarat analisis berupa uji normalitas dan uji homogenitas pada data yang di 
dapatkan. Uji prasayarat analisis dilakukan sebagai syarat untuk melakukan uji parametrik yaitu data yang dimiliki harus berdistribusi normal dan berasal dari populasi yang memiliki variance yang homogen (Lukman, 2017). Adapun hipotesis yang diajukan oleh peneliti ialah :

$\mathrm{H}_{0}$ : Terdapat hubungan yang positif antara kesehatan mental terhadap hasil belajar anak usia 56 tahun di Lembaga PAUD di Kabupaten Sukabumi $\mathrm{H}_{1}$ : Tidak terdapat hubungan yang positif antara kesehatan mental terhadap hasil belajar anak usia 56 tahun di Lembaga PAUD di Kabupaten Sukabumi Untuk membuktikan hipotesis tersebut akan dilakukan uji regresi Linear sederhna dengan rumus

1) Uji Koefisien Korelasi Pearson (r), menurut (Sugiyono, 2015) :

$\mathrm{r}_{\mathrm{xy}}: \frac{n \sum x_{\mathrm{i}} y_{\mathrm{i}}-\left(\sum x_{\mathrm{i}}\right)\left(\sum y_{\mathrm{i}}\right)}{\sqrt{\left\{n \sum x_{\mathrm{i}}^{2}-\left(\sum x_{\mathrm{i}}\right)^{2}\right\}\left\{n \sum y_{\mathrm{i}}{ }^{2}-\left(\sum y_{\mathrm{i}}\right)^{2}\right.}}$

Keterangan :

$\mathrm{r}=$ Koefisien Korelasi Pearson

$\mathrm{X}=$ Variabel Bebas

$\mathrm{Y}=$ Variabel Terikat

$\mathrm{n}=$ Jumlah Sampel

2) Koefisien Determinasi

\section{$K d=(K K)^{2} \times 100 \%$}

Dimana KK adalah Koefisien Korelasi. Nilai Koefisien Determinasi pada Regresi akan menunjukkan nilai berapa persen kesehatan mental dapat berpengaruh terhadap hasil belajar anak usia 5-6 tahun.

\section{HASIL DAN PEMBAHASAN}

Kondisi mental atau kesehatan mental merupakan hal yang sangat penting seperti halnya kesehatan fisik pada umumnya. Masalah pada kesehatan mental emosional anak akan menurunkan produktivitas dan kualitas hidup anak serta menghambat perkembangannya. Kesehatan mental anak sangat erat kaitannya dengan kecerdasan emosional yang dimiliki anak. Menurut (Fitriyani, 2015) "Kecerdasan emosi merupakan kecerdasan yang memusatkan perhatian dalam mengenali, memahami, merasakan, mengelola, dan memotivasi baik diri sendiri maupun orang lain serta dapat mengaplikasikan kemampuan tersebut dalam kehidupan pribadi dan sosialnya". Maka perlu memberikan pendidikan kepada anak untuk memiliki kecerdasan emosional yang berguna untuk mengendalikan emosi dengan memotivasi diri dan bertahan dalam menghadapi situasi permasalahan, tidak melebihkan rasa senang, menghadapi frustasi, mengatur suasana hati dan terhindar dari stres, tetap meningkatkan kemampuan berpikir, berempati dan berdoa (Susilowati, 2018).

Menurut hasil jawaban para responden terhadap 17 pernyataan positif yang terdapat dalam angket menghasilkan presentsi sebagai berikut :

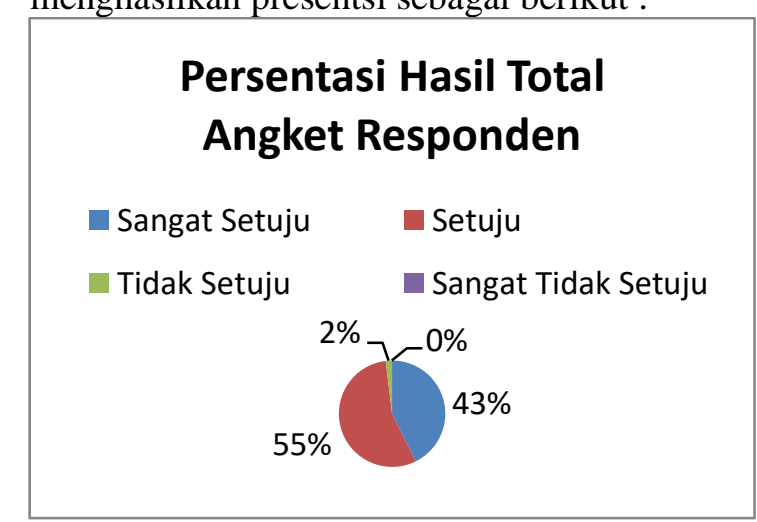

Gambar 1 hasil total angket

Dari diagram di atas menunjukkan bahwa $43 \%$ responden menyatakan sangat setuju, 55\% setuju, $2 \%$ tidak setuju dan $0 \%$ sangat tidak setuju. Artinya, 98\% responden menjawab bahwa terdapat hubungan antara kesehatan mental terhadap hasil belajar.

Melalui olah data dengan uji regresi linear sederhana maka dapat dilihat tabel 1 .

Tabel 1. Uji egresi sederhana

\section{Model Summary}

\begin{tabular}{llrrr}
$\begin{array}{l}\text { Mod } \\
\text { el }\end{array}$ & R & $\begin{array}{c}\text { R } \\
\text { Square }\end{array}$ & $\begin{array}{c}\text { Adjusted } \\
\text { R Square }\end{array}$ & $\begin{array}{c}\text { Std. Error } \\
\text { of the } \\
\text { Estimate }\end{array}$ \\
\hline 1 &, $665^{\text {a }}$ &, 442 &, 429 & 2,05224 \\
\hline
\end{tabular}

Dari tabel di atas dapat diketahui nilai $\mathrm{R}$ bernilai positif yaitu 0,665 yang dapat menunjukkan bahwa terdapat hubungan yang positif antara variabel $\mathrm{X}$ Kesehatan Mental terhadap Variabel Y yaitu Hasil Belajar Anak usia 5-6 tahun. hubungan positif disini 
PISSN 2548-6284 E ISSN 2615-0360

Vol. 6 No. 1 Desember 2021

diartikan bahwa apabila kesehatan mental anak meningkat atau baik, maka hasil belajar anak pun akan meningkat/baik. Berdasarkan tabel pedoman Interpretasi Koefisien Korelasi di atas, nilai $\mathrm{R}$ menunjukkan angka 0,665 artinya terjadi hubungan yang kuat antara Kesehatan mental (X) terhadap hasil belajar anak usia 5-6 tahun (Y).

Koefesien determinasinya ialah :

$$
\begin{aligned}
\mathrm{Kd} & =(\mathrm{KK})^{2} \times 100 \% \\
& =(0,665)^{2} \times 100 \% \\
& =44,22 \%
\end{aligned}
$$

Berdasarkan penghitungan rumus koefisien determinasi di atas maka dapat dinyatakan bahwa $44,22 \%$ hasil belajar anak usia 5-6 tahun dipengaruhi oleh kesehatan mental. Sedangkan $55,78 \%$ lainnya dipengaruhi oleh hal-hal lain yang berada di luar penelitian.

Tabel 2. Uji regresi linier sederhana

Berdasarkan hasil Uji Regresi linear sederhana di atas dapat dilihat bahwa nilai $\mathrm{F}$ hitung $=32,516$ dengan nilai nilai signifikansi sebesar 0,000 $<0,05$ maka dapat dinyatakan bahwa kesehatan mental berpengaruh secara signifikan terhadap hasil belajar

\section{ANOVA $^{b}$}

\begin{tabular}{lllllll}
\multicolumn{9}{c}{$\begin{array}{l}\text { Sum of } \\
\text { Square }\end{array}$} & & & & \\
Mean & & \\
& & s & df & Square & F & Sig. \\
\hline 1 & Regre & 136,94 & 1 & 136,94 & 32,5 &, 000 \\
& ssion & 8 & & 8 & 16 & a \\
Resid & 172,68 & 41 & 4,212 & & \\
ual & 0 & & & & \\
\hline
\end{tabular}

anak usia 5-6 tahun.

Berdasarkan hasil penelitian dapa disimpilkan bahwa kondisi kesehatan mneatal anak akan sangat berpenyaruh pada hasil belajar anak usia 5-6 tahun, hubungan antara variabel $\mathrm{x}$ dan $\mathrm{y}$ menunjukkan hubungan yang kuat dan posittif artinya apabila kesehatan mental meningkat maka hasil belajar anak pun akan meningkat begitu pun sebaliknya apabila kesehatan mental anak menurun amak hasil belajar anak pun akan menurun.
Inti dari kesehtan mental anak tercantum dalam aspek perkembangan anak yaitu pada aspek sosial emosional dan terperinci dalam Standar Tingkat Pencapaian Perkembangan Anak (STPPA) dalam (Kementrian Pendidikan dan Kebudayaan RI, 2018).

Berdasarkan hasil statistik terhadap survey yang dilakukan pada seluruh sampel menunjukkan bahwa hipotesis yang diajukan oleh peneliti diterima dimana kesehatan mental memiliki hubungan positif terhadap hasil belajar anak dengan nilai keberpengaruhan sebesar 44,22\%. Dengan ini, kesehatan mental menunjukkan pengaruh yang cukup besar terhadap hasil belajar anak dimana hasil belajar anak akan meningkat ketika kesehatan mentalnya baik. Sedangkan 53,88\& lainnya dapat dipengaruhi oleh faktor-faktor lain diluar dari penelitian.

Mental emosional merupakan suatu upaya untuk menyesuaikan diri dengan lingkungan dan pengalaman-pengalamannya (Rizkiah et al., 2020). Kondisi mental atau kesehatan mental merupakan hal yang sangat penting seperti halnya kesehatan fisik pada umumnya. Masalah pada kesehatan mental emosional anak akan menurunkan produktivitas dan kualitas hidup anak serta menghambat perkembangannya. Kesehatan mental anak sangat erat kaitannya dengan kecerdasan emosional yang dimiliki anak. Menurut (Fitriyani, 2015) Kecerdasan emosi merupakan kecerdasan yang memusatkan perhatian dalam mengenali, memahami, merasakan, mengelola, dan memotivasi baik diri sendiri maupun orang lain serta dapat mengaplikasikan kemampuan tersebut dalam kehidupan pribadi dan sosialnya. Maka perlu memberikan pendidikan kepada anak untuk memiliki kecerdasan emosional yang berguna untuk mengendalikan emosi dengan memotivasi diri dan bertahan dalam menghadapi situasi permasalahan, tidak melebihkan rasa senang, menghadapi frustasi, mengatur suasana hati dan terhindar dari stres, tetap meningkatkan kemampuan berpikir, berempati dan berdoa (Susilowati, 2018). Berdasarkan hasil statistik terhadap survey yang dilakukan pada 
P ISSN 2548-6284 E ISSN 2615-0360

Vol. 6 No. 1 Desember 2021

seluruh sampel menunjukkan bahwa hipotesis yang diajukan oleh peneliti diterima dimana kesehatan mental memiliki hubungan positif terhadap hasil belajar anak dengan nilai keberpengaruhan sebesar 44,22\%. Dengan ini, kesehatan mental menunjukkan pengaruh yang cukup besar terhadap hasil belajar anak dimana hasil belajar anak akan meningkat ketika kesehatan mentalnya baik. Sedangkan 53,88\& lainnya dapat dipengaruhi oleh faktor-faktor lain diluar dari penelitian.

Dengan sehatnya mental seseorang maka aspek kehidupan yang lain dalam dirinya akan bekerja secara lebih maksimal (K \& Dewi Aisyah, 2021).

Menurut Zakiyah Daradjat (dalam Ariadi, 2013), karakteristik mental yang sehat ialah, terhindar dari gangguan jiwa; penyesuaian diri (self adjustmenti); pemanfaatan potensi maksimal dan tercapainya kebahagiaan pribadi dan orang lain. Faktor-faktor yang dapat melindungi anak dari gangguan kesehatan mental diantaranya: kecerdasan emosi, dicintai dan merasa aman, tinggal dilingkungan rumah yang stabil, pekerjaan orang tua juga cukup mempengaruhi terhadap kesehatan mental, karena akan berdampak pada faktor ekonomi keluarga, orang tua yang baik dan kesehatan mental orang tua yang baik serta kegiatan rutinitas dan minat anak, hubungan yang positif dengan sesamanya, ketahanan emosional dan berfikir positif juga rasa humor (Suminar \& Hamidah, n.d.).

Inti dari kesehtan mental anak tercantum dalam aspek perkembangan anak yaitu pada aspek sosial emosional dan terperinci dalam Standar Tingkat Pencapaian Perkembangan Anak (STPPA) dalam (Kementrian Pendidikan dan Kebudayaan RI, 2018). Hasil belajar anak usia dini yaitu serangkaian aktivitas mengukur dan menilai pencapaian kemampuan anak usia dini pada aspek-aspek perkembangannya secara menyeluruh dalam proses pembelajaran (Safitri \& Miranda, 2009).

Hasil belajar anak usia dini dapat dipengaruhi oleh faktor internal dan eksternal. Faktor internal ialah semangat, motivasi diri dan juga kesehatan baik fisik maupun mental anak. Undang-Undang No 23 Tahun 1992 menyebutkan bahwa sehat adalah keadaan sejahtera dari badan (jasmani), jiwa (rohani) dan sosial yang memungkinkan setiap orang dapat hidup produktif secara sosial dan ekonomis (Fuadi Husin, 2014). Sedangkan menurut (Dewi, 2012) Sehat merupakan suatu kesejahteraan secara umum atau sempurna baik secara fisik, mental ataupun sosialdan tidah hanya terhindar dari kondisi lemah dan penyakit saja. Faktor-faktor yang dapat melindungi anak dari gangguan kesehatan mental diantaranya: kecerdasan emosi, dicintai dan merasa aman, tinggal dilingkungan rumah yang stabil, pekerjaan orang tua juga cukup mempengaruhi terhadap kesehatan mental, karena akan berdampak pada faktor ekonomi keluarga, orang tua yang baik dan kesehatan mental orang tua yang baik serta kegiatan rutinitas dan minat anak, hubungan yang positif dengan sesamanya, ketahanan emosional dan berfikir positif juga rasa humor.

\section{SIMPULAN}

Hasil belajar anak usia dini dapat dipengaruhi oleh faktor internal dan eksternal. Faktor internal ialah semangat, motivasi diri dan juga kesehatan baik fisik maupun mental anak, sehat merupakan suatu kesejahteraan secara umum atau sempurna baik secara fisik, mental ataupun sosialdan tidah hanya terhindar dari kondisi lemah dan penyakit saja.

Melalui penelitian ini, dapat disimpulkan bahwa kesehatan mental memiliki hubungan dan berpengaruh terhadap hasil belajar anak usia 5-6 tahun di Kecamatan Parungkuda Kabupaten Sukabumi. Apabila kesehatan mental seorang anak baik maka hasil belajar yang ditunjukkan oleh anak pun akan baik begitupun sebaliknya. Hal ini menunjukkan bahwa kesehatan mental sama pentingnya dengan kesehatan fisik yang perlu dianalisis dan diberikan stimulasi yang baik oleh orang-orang terdekat baik orang tua, guru maupun masyarakat. Perlu adanya nya peningkatan dalam kualitas pembelajaran anak usia dini di khususnya di Kecamatan Parungkuda untuk memberikan rasa nyaman, aman dan bahagia dalam setiap proses pembelajarannya. 


\section{DAFTAR PUSTAKA}

Dewi, K. S. (2012). Buku Ajar Kesehatan Mental. In UPT UNDIP Press Semarang (1st ed.). CV. Lestari Mediakreatif.

Fakhriyani, D. V. (2019). KESEHATAN MENTAL (M. Thoha (ed.); 1st ed.).

Fitriyani, L. (2015). Peran pola asuh orang tua dalam mengembangkan kecerdasan emosi anak. Lentera, 17(1), 93-110.

Fuadi Husin, A. (2014). Islam Dan Kesehatan. Islamuna: Jurnal Studi Islam, 1(2). https://doi.org/10.19105/islamuna.v1i2.567

K, F., \& Dewi Aisyah. (2021). Peningkatan Kesehatan Mental Anak Dan Remaja Melalui Ibadah Keislaman. Al-Isyrof: Jurnal Bimbingan Konseling Islam, 3(1), 1-7. https://doi.org/10.51339/isyrof.v3i1.292

Kementrian Pendidikan dan Kebudayaan RI. (2018). Permendikbud Nomor 146 Tahun 2014: Tentang Kurikulum 2013 PAUD. Direktorat Pembinaan PAUD.

Lukman, H. S. (2017). ANALISIS DATA KUANTITATIF : Menggunakan Software SPSS (A. Imswatama (ed.); 1st ed.). CV. Nurani.

Pane, A. (2017). Belajar dan Pembelajaran. Jurnal Kajian Ilmu-Ilmu Keislaman, 03(2), 333-352.

Puspita, S. M. (2019). Kemampuan Mengelola Emosi Sebagai Dasar Kesehatan Mental Anak Usia Dini. SELING: Jurnal Program Studi PGRA, 5(1), 8592.

Rizkiah, A., Risanty, R. D., \& Mujiastuti, R. (2020). Sistem Pendeteksi Dini Kesehatan Mental Emosional Anak Usia 4-17 Tahun Menggunakan Metode Forward Chaining. JUST IT: Jurnal Sistem Informasi, Teknologi Informasi Dan Komputer, $10(2), \quad 83$. https://doi.org/10.24853/justit.10.2.83-93

Safitri, U., \& Miranda, D. (2009). PELAKSANAAN PENILAIAN HASIL BELAJAR ANAK USIA DINI DI TK LIA II PONTIANAK.

Sugiyono. (2015). METODE PENELITIAN : Kuantitatif, Kualitatif, dan $R \& D$ (22nd ed.). Alfabeta.

Suminar, D. R., \& Hamidah. (n.d.). Membangun kesehatan mental anak usia dini dengan pengasuhan positif. 2(1), 13-20.

Susilowati, R. (2018). Kecerdasan Emosional Anak Usia Dini. ThufuLA: Jurnal Inovasi Pendidikan Guru Raudhatul Athfal, 6(1), 145. https://doi.org/10.21043/thufula.v6i1.4806

Suwardi, S., Firmiana, M. E., \& Rohayati, R. (2016). Pengaruh Penggunaan Alat Peraga terhadap Hasil Pembelajaran Matematika pada Anak Usia Dini. JURNAL Al-AZHAR INDONESIA SERI HUMANIORA, 2(4), 297. https://doi.org/10.36722/sh.v2i4.177

Yusup, F. (2018). UJI VALIDITAS DAN RELIABILITAS. Jurnal Tarbiyah, Jurnal Ilmiah Kependidikan, 7(1), 17-23. 